\title{
THE ROLE OF THE SOCIAL CAPITAL IN RURAL DEVELOPMENT. CASE STUDY ANALYSIS OF VILLAGE RESEARCH CAMPS IN ROMANIA AND HUNGARY
}

Tibor Farkas ${ }^{1}$

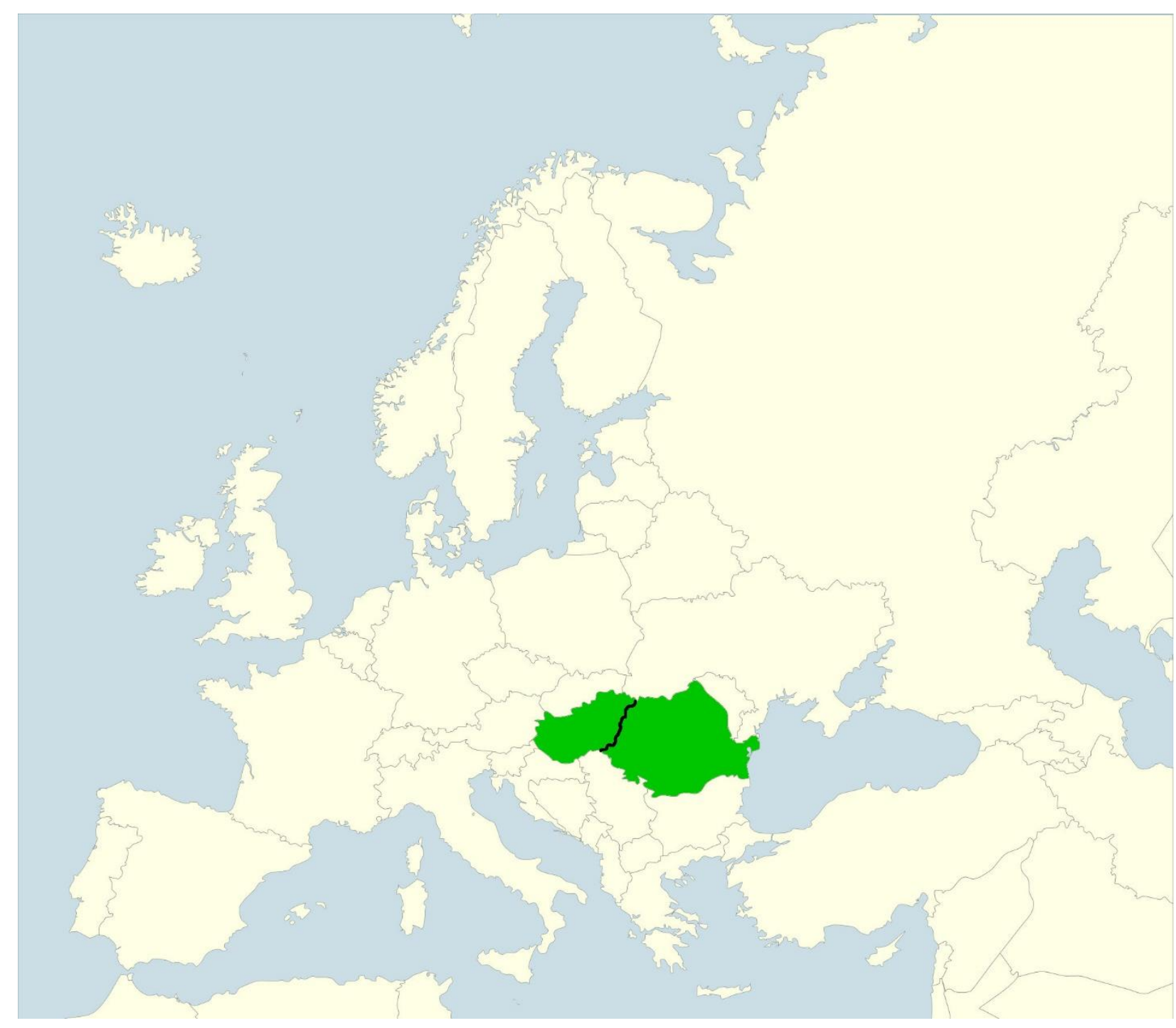

${ }^{1}$ Dr. Tibor Farkas, PhD. habil., associate professor, Hungarian University of Agriculture and Life Sciences, Gödöllö, ORCID: 0000-0002-6645-377X, e-mail: farkas.tibor.kumacs@gmail.com 
Abstract: Social capital represents an increasingly used term in social sciences, but its application in rural development is not widespread. In this study, we assess the social capital of villages where we have organized village research camps over the past decade. The research utilizes a specific methodology, synthesizes the research carried out in the village research camps. Methods included statistical data analysis, questionnaire survey, interviewing, and participant observation. Among the results, we found that the social capital of the studied villages and the condition of their local communities are different. These also affected the effectiveness of development activities. The study examined the role of social capital and how the development of social capital can contribute to the development of villages. In summary, our assumption is that there is a link between social capital and rural development, but this relationship is not always evident or one-way.

Keywords: Social capital, rural development, community, participation, local development

Absztrakt: A társadalmi tőke a társdalomtudományban egyre gyakrabban használt fogalom, de a vidékfejlesztésben való alkalmazása nem terjedt el. Ebben a tanulmányban olyan falvaknak a társadalmi tőkéjét mérjük fel, ahol az elmúlt évtizedben falukutató táborokat szerveztünk. A kutatás sajátos módszertant alkalmaz, a falukutató táborokban végrehajtott kutatásokat szintetizálja. A módszerek között szerepelt a statisztikai adatok elemzése, kérdőíves felmérés, interjú készítése és résztvevő megfigyelés is. Az eredmények között megállapítottuk, hogy a vizsgált falvak társadalmi tőkéje és a helyi közösségeik állapota különböző. Ezek befolyásolták a fejlesztési tevékenységek eredményességét is. A tanulmány a társadalmi tőke szerepét vizsgálta, illetve azt, hogy a társadalmi tőke fejlesztése hogyan járulhat hozzá a falvak fejlödéséhez. Összefoglalva a feltételezésünk az, hogy a társadalmi tőke és a vidékfejlesztés között van kapcsolat, de ez a kapcsolat nem minden esetben egyértelmű vagy egyirányú.

Kulcsszavak: Társadalmi tőke, vidékfejlesztés, közösség, részvétel, helyi fejlesztés

\section{Highlights:}

- In the current research, the relationship of development and social capital was analyzed with the help of case studies.

- As methodology research camp method was used, in seven villages in the last decade.

- The examination of the relationship between social capital and development is still incomplete, the relationship between them can only be assumed. However, it seems the same development results in a better quality of life with higher social capital.

- Furthermore, if social capital is higher, the success of development is more certain.

\section{Introduction}

There is a growing body of research on the benefits and use of social capital. However, there is still little practical experience of its application in rural development. Methods for examining social capital at local level are not yet elaborated. This is especially true for analyzing rural communities, because it would be very difficult to conduct general, settlement-level surveys. In the current study, after a review of the literature, we will present some of the results in this area obtained in Romanian and Hungarian summer village research camps. 
The organization of village research camps at Hungarian University of Agriculture and Life Sciences $^{2}$ began in the early 1990 s. On the one hand, the camps provide the opportunity for students and trainers to gain direct experience in researching local societies and economies and, on the other hand, the villages surveyed receive a systematic, science-based mirror of their own situation, social problems and opportunities. An important feature of the one-week camps is that students, trainers, or even high school students with different interests, participate in close cooperation with those living in the village. The results of the research are always published in a volume which local people receive.

One of the most important research questions was (and remains) how local society is fit to engage in rural or local development and what social conditions boost or hinder the local development. Further questions could be whether strong community participation and social capital could compensate for the inherited disadvantage and contribute to development. How do local conflicts affect development opportunities? What is the role of the social capital in the development process? In the course of our studies, we also accept the Gusti's Law of parallelism that there is no single phenomenon in the life of society, no single manifestation of life, which is isolated, independent, and self-explanatory (Gusti, 1976).

\section{Social capital and rural development}

Although the concept of social capital has long been known, it only spread spectacularly in the literature in last decades. Social capital was first used in literature in the beginning of the 20th century by Lyda Judson Hanifan (Tömpe, 2007), but it only became widely known in the 1990s. Although the use of social capital in rural development is being urged (e.g. Pisani, Micheletti, 2020; Kulcsár, 2017; Wiesinger, 2007; Dufhues et al., 2006; Orbán, Szántó, 2005), its practical application has not yet been widespread. Social capital has been given a number of different definitions, such as Bourdieu (1986), Coleman (1988), Putnam (1993) Fukuyama, 2001), but there has not been a generally accepted one yet, even though most of the authors would agree that social capital is a mixture of relations, trust, civil social activity and norms regulating social behaviour.

The issue of social capital is increasingly coming to the fore in development studies (SchafftBrown, 2003). The strong network of trust-based, mutually beneficial relationships presupposes a strong local society where NGOs are active, communication between people is frequent, and there is a high level of trust in each other, strangers and the institutional system. Social capital could be a resource of community. It means close relationships between members of the community that are based on trust (see Füzér et al., 2005).

According to Dunens, four types of trust can be built: contractual, communication, competence, and caring trust. Contractual trust is strong when people fulfil their commitments; when they do what they say. Communication trust is more nuanced: a clear and frequent communication helps people follow rules, support local affairs, and embrace change. We talk about competence confidence when people are proficient in what they do and can prove that they can do their job well. Caring is the softer side of trust: with caring trust, we can believe that even if something doesn't work out in the community, leaders still tried to act in their best interests (Hoelting, 2017).

Social capital has a place in the "rural network." It is among the six theoretical dimensions that the developers of the model (van der Ploeg and Marsden, 2008; in Guinjoan et al., 2016) believe can overcome the decline of agriculture and improves the quality of life in rural areas. These dimensions are endogeneity, novelty production, sustainability, social capital, new institutional frameworks and market governance; the relationships formed between these dimensions are fundamental to the strength and ultimately to the development of the area's 'rural network' (Guinjoan et al., 2016).

Rosenqvist (2020; in: Pisani, Micheletti, 2020) emphasizes, that social capital theories bring to the fore the idea that rural development processes are complex phenomena embedded in social

\footnotetext{
2 Previous names: Agricultural University of Gödöllő, Szent István University Gödöllő.
} 
structures and other contextual contexts where participants' goals are not based solely or necessarily on self-interest. On the other hand, new urban-rural relations are not based just on biological need, but primarily on new social needs and requirements. This means that social norms, values, and attitudes largely determine the establishing or development of new urbanrural relationships (Westlund and Kobayashi, 2013). According to Böhm and Pál (1983) the crucial mechanisms for local society ${ }^{3}$ are: production and consumption, public life and communication. With help of those channels, they are primarily linked to society or their framework of life is regulated by the whole society (Böhm and Pál, 1983).

Social capital cannot be thought of as a property of closed and bounded rural communities, which merely perpetuates the myths of rurality as a preserve of old traditions. And yet, on the other hand, it is very much linked to ideas of place and identity. Where social capital brings benefits, it is likely to be associated with a plurality of cultural identities, a plethora of diverse networks of social relationships and strong links to the multiple historical themes that characterise European rural areas (Lee et al. 2005). Bíró's opinion highlights the importance of local identity and the status and functions of local communities. In a resource-deficient region, external support, external stimulation and support for development processes is obviously important for local development. But it is as important as the inclusion of endogenous capacities. In order to gradually begin to develop and organize themselves for a settlement in a peripheral situation today, the existence or absence of these local-scale community reserves may be crucial (Bíró, 2002). Lee et al. (2005) state, that a focus on networks of social relationships can help understand the dynamics of the relationship between social capital and identity and their place in development. In other words, a focus on social networks can provide a means of understanding the specifics of social capital and identity in action.

Social capital is a neutral resource that can serve both constructive and disruptive purposes. The aim of the policy may be to fight against phenomena that push social capital in a negative or dark direction. Social capital can also be undermined by policies that seem to have nothing to do with it. For example, the closure of schools, railways or public services can disrupt social networks (Wiesinger, 2007). Examining school closures in Poland, Kłoczko-Gajewska (2020) concluded that local authorities can influence the social capital of village residents. They are not able to create on their own in places where such capital does not exist, but they can easily destroy it with different decisions. At the same time, villages with strong institutional social capital are more likely to succeed (Kłoczko-Gajewska, 2020). The closure of local schools generally reduces social capital not just in Poland, but in Romania and in Hungary, too (Kassai et. al., 2016; Semczuk, 2020). However, villages with strong social capital are more successful in tackling school closures, with greater potential for success, which is a further motivator for joint action. Otherwise, communities suffering from a lack of social capital are threatened with a vicious circle of weakness and despair. The lack of joint initiatives resulting from school closures can affect the younger generation and, in the long run, lead to a weakening of cognitive social capital (Kłoczko-Gajewska, 2020).

Trigilia (2001; in: Pisani, Micheletti, 2020) notes that concepts of social capital do not jeopardize the role of the state in favour of the market. In other words, public institutions need to work "from above" to help local actors network, collaborate or coordinate "from below" in order to achieve common goals based on the new governance approach. Governments can encourage participation in local organizations, for example, by creating an environment in which organizations can operate and communicate effectively. Nevertheless, it is difficult and perhaps too early to make sensible policy recommendations for promoting social capital. (Wiesinger, 2007).

The government should only intervene in the functioning of society by developing social capital with reservations and conditions. Due to the embeddedness of social capital in cultural and

\footnotetext{
3 "In the first approach, a local society is a social formation that is spatially separated, has specific qualities, interest structures, hierarchical stratification, and is able to express its interests with more or less autonomy within the economic and social institutional system. Its members are characterized by subordinate, superordinate or co-ordinate relations, as well as an identity consciousness related to the given locality." (Bőhm and Pál, 1983; p.14.)
} 
historical processes, rapid and spectacular change is not expected to occur because of government efforts. The government must also ensure that the effect of the development of social capital is favourable from the point of view of the well-being of the society (Füzér et al., 2005). According to Luloff and Bridge (2003), community development strategies based on the concept of social capital direct attention to restore relationships lost during modernization. At the same time, the interaction approach focuses on the continuing features of local social life. Development policy must address the fact that many of the problems of local communities are not of local origin. Because the relationship between community action and well-being is stable, local community development ${ }^{4}$ should be an important element of the development policy (Luloff and Bridge, 2003). They promote rural development initiatives in a synergistic way by promoting policies that encourage the accumulation of social capital, participation, cooperation, and coordination of multistakeholder projects (Rivera et al., 2018b; in: Pisani and Micheletti, 2020).

Several authors take a more critical view of the role of social capital. According to Lee et al. (2005), fostering networks and social capital are examples of interventions in the process of development that can have long-term beneficial results. At the same time, networks and social capital can be used by individuals or groups to limit the supply or extent within the population of benefits resulting from change. The importance of these often-overlooked aspects of development is thus established (Lee et al. 2005). Polèse and Shearmur (2005) used different attributes (city system, market size, market accessibility, producer services, industrial mix, local entrepreneurship, social capital, innovative milieus, learning regions, etc.) for their analysis. The authors doubt the decisive role of the social capital: "What if the sources of decline (or success, for that matter) lie elsewhere? To imply that peripheral regions of the type portrayed here are declining due to a lack of social capital or of deficient local entrepreneurship and innovation is not only misleading, but may also be counterproductive (Polèse and Shearmur, 2005; p. 43.)."

Research shows that social capital has a positive impact on household well-being and economic development, but it is not clear enough how social capital affects economic growth and whether there are cases where it should be limited. In addition, the negative aspects of social capital have often been completely ignored. Social capital, like all other factors of production, can be used for both constructive and disruptive purposes. For example, "good relationships" may provide easier access for certain individuals to public procurement or easier comply with certain regulations (Dufhues et al., 2006). At the same time, strong social capital can cause social exclusion for all those who are unable or unwilling to accept local norms. Strong relationships within a closed community can result in rejection of innovation and newcomers or even xenophobia (Wiesinger, 2007).

Corruption is linked to a lack of trust in institutions and in others. Low trust in institutions fosters corruption as a way to reduce the uncertainty of an unpredictable social environment (Voicu and Basina, 2005). While in Romania, corruption plays an important role in everyday interactions; in Hungary several researchers draw attention to the importance of public or state corruption. Fazekas and Tóth (2010) state, it is not clear whether the centralisation of corruption and state capture is due to the restructuring of the public administration or to the composition of the ruling elite in Hungary. According to the analysis of Swendsen (2003), a high level of corruption and the lack of trust in the government affect negatively the level of trust and social capital among citizens. Corrupt countries with the lowest levels of trust also have smaller Gross Domestic Product per capita levels (Swendsen, 2003).

The atrophy of local infrastructure leads to a further decline in economic and cultural capital and ultimately social capital. The structure of social capital needs to adapt to new challenges and

\footnotetext{
${ }^{4}$ Here it is useful to draw the distinction between development in community and development of community (Claude et al. 2000; Summers 1986; Wilkinson 1991). Development in community refers to such instrumental activities as job creation, business retention, expansion, recruitment, and infrastructure improvements. In contrast, development of community focuses on the social aspects of local life, and emphasizes the enhancement of local problem solving capacities (Luloff and Bridge, 2003).
} 
developments and new challenges will be met by novel organizations. The biggest challenge for the future lies in understanding political structures (Wiesinger, 2007).

While investigating the community factor of the development, we will use the following theoretic grid. Table 1. shows a direct relationship between social capital and the success of the development. It is suggested, that in the case of high social capital and efficient development activities, there are good opportunities for development.

Fig 1. The social-economic characteristics of rural development. Source: own contribution

\begin{tabular}{|l|l|l|}
\hline \multirow{2}{*}{$\begin{array}{l}\text { Type of } \\
\text { development }\end{array}$} & Social capital & Low \\
\cline { 2 - 3 } & High & $\begin{array}{l}\text { Successful development based on } \\
\text { the dominant role of local elite and } \\
\text { external resources }\end{array}$ \\
\hline $\begin{array}{l}\text { Successful } \\
\text { development }\end{array}$ & $\begin{array}{l}\text { Efficient cooperation of community } \\
\text { members and partners in rural } \\
\text { development, developing community }\end{array}$ & $\begin{array}{l}\text { Weak social capital, extensive } \\
\text { development efforts, weak } \\
\text { leadership }\end{array}$ \\
\hline $\begin{array}{l}\text { Ineffective } \\
\text { development }\end{array}$ & $\begin{array}{l}\text { Ineffective use of internal and } \\
\text { external resources, negative social } \\
\text { capital }\end{array}$ & \multicolumn{2}{|l}{} \\
\hline
\end{tabular}

\section{Applied methods and data}

The approach and the methods of village research in Hungary changed a lot over the decades. The village researchers in the 1930s explored the village's problems from a sociographic point of view. After the Second World War traditions of village research were revived especially among ethnographers. At the end of the 1980s, there was a significant change in the approach and method of research. According to various authors (e.g. Ludescher, 2009), in this period, the sociographic method lost its importance.

The study of social capital and rural development was examined within the framework of village research camps. We carried out research on predetermined topics (quality of life, happiness, social networks, anomie, informal economy, sector analysis) in the village research camp. The importance of different topics of the camps has changed, but the analysis of the local society stayed permanent over the years. The village camp research included questionnaire survey, interviewing, participant observation and the analysis of local and official statistical data every time.

In the course of our research, we relied primarily on the applications of the Romanian National Institute of Statistics (INS) and the Hungarian Central Statistical Office. Census databases also play an important role in demographic research. Local databases consist of local government and church registers. We used Excel and SPSS for analysis.

A total of seven questionnaire surveys was conducted with help of interviewers ${ }^{5}$. In addition, in some villages, an online questionnaire survey was also complemented beside the paper-based one. With the questionnaires, we visited the households and tried to interview the head of the household. If he was not at home, we asked his or her spouse. If they were both at home, we asked them, in most of the cases together. In several Transylvanian villages, the pattern is skewed towards more elderly women, as many middle-aged men frequently work abroad. The essence of the sampling was to interview every second or third household. In the case of

\footnotetext{
5 Number of questionnaires completed and interviews conducted: V 91 questionnaires, 11 interviews; $M 151$ questionnaires, 8 interviews; Z 80 questionnaires, 13 interviews; I 55 questionnaires, 13 interviews; B 237 questionnaires, 21 interviews; K 228 questionnaires, 14 interviews; T 299 questionnaires, 22 interviews.
} 
online questionnaires, the questionnaire was conducted among young people. In most cases, students completed the questionnaire in upper grade classes with the help of teachers. In this case, basically all members of the given age group were reached.

Frequency distributions were calculated from the data obtained during the research, and the results were presented with help of diagrams and tables while analyzing the relationships between metric variables with the help of cross-table analysis. In addition to quantitative research, the collection of qualitative data was equally important. The interviews revealed who was the authoritative, decision-making, opinion-forming personality of the village. Participant observation means observation of everyday life, work, consumption habits and participation in festive events. Based on the existing development case studies, we aimed at drawing general conclusions about the functioning of social capital.

\section{Development and social capital in analyzed villages}

In the following, we summarized the essence of seven case studies. Settlements are marked with only one capital letter, because in this case their actual location or name is less interesting. It is much more important that the history of their development, the presentation of the role of the local community helps to answer our research questions.

\section{V village}

$\mathrm{V}$ is located in Romania, in the county of Mures, in Transylvania. The majority of the population about 400 people is mostly of Hungarian nationality. $\mathrm{V}$ is the center of $\mathrm{V}$ commune with three villages. The population dynamics of the settlement is unfavourable; over the past half-century, the number of births has dropped dramatically. The mortality rate was well above the live birth rate, so the population of the village is constantly decreasing. At the same time, immigration has affected the village. All of this led to a distortion of the age structure and aging. The unfavourable age composition is also related to unemployment and to higher proportion of dependents. The vast majority of the village population is economically inactive: pensioners, housewives or dependents.

The older or disadvantaged inhabitants of the village find it difficult to adapt themselves to the changing social environment, and many of them are uncertain, uninformed and are able to make decisions with difficulty. But there are some traditional values that hold the community together. Relationships within families or among friends help them cope with the difficult living conditions, but on the other hand, formal collaboration or co-operation remains at a low level.

The most important development opportunity is the village preservation and rural tourism program, with the leadership of the mayor, who is functioning as a real 'local hero. ${ }^{6}$ The resources for that development come primarily from outside, and in case of failure, this program could face serious difficulties. Developing tourism is not an easy task as it cannot be operated without the involvement of the local community, which, in this case is not yet ready for the task. The development opportunities of the village were limited by the following factors: low interest in establishing new businesses (entrepreneurship), the lack of (tourism) infrastructure, lack of microregional co-operation and relying mainly on external resources (Farkas and Dávid, 2010).

\section{M village}

$M$ is a commune center with 1,600 inhabitants, in the county Mures, too. During the socialist period, the population of the village decreased dramatically. Recently, the demographic situation is still characterized by stagnation, with a relatively high birth rate and lower death rate.

In $\mathrm{M}$, the changes began in 2001 as the development plan of the settlement was completed, in which important and well-grounded proposals were made regarding the development of

\footnotetext{
${ }^{6}$ Local heroes are people who, using their own energy, time and talent, can generate spectacular development in different settlements. However, community participation and support is often lacking.
} 
the village. One of the most important objectives, the restoration of self-government, was implemented in 2004 after a two-year struggle. Another important development proposal was the improvement and paving of the dirt road network. Important progress has also been made in farming. Experts have correctly proposed dairy cattle breeding which already had traditions in M. Another important factor was the formation of the farmer's association (Farkas, 2010).

Women usually have an important role regarding development activities, but the position and the possibilities of women is determined by culturally fixed constraints. According to the local norm, a woman's place is in her home, and leaving the village is frowned upon. As a result, these socio-cultural rules make it almost impossible for women to commute and work in urban centres. We also considered the state of the local society rather weak. Co-operation between individuals was very weak, people were unsatisfied with the services, and they were not involved in local decisions. The supply of services is poor; the low level of education is associated with a lowincome situation and a lack of innovation, and inefficient functioning of the local management.

In summary, M's development problems were the following: the developments started with external help, improvements were made primarily through the introduction of external information, uninterested local community, envy, and distortion between the mayor, village representatives and the development association, the disadvantaged situation of women and strong influence of party politics.

\section{Z village}

The village with a population 321 is a peripheral settlement. It is located north of Huedin (Bánffyhunyad) in Salaj County, Romania and administratively belongs to Almaşu (Váralmás). In the second half of the $20^{\text {th }}$ century, the population of the village was mainly reduced by outmigration, caused by migration to urban workplaces and forced urbanization. By now, the weight of migration processes has decreased, with further loss of population caused by extremely low birth rates and increasing mortality rates. Overall, the current demographic situation in the settlement shows a negative picture for the future.

Our research has highlighted that the social capital of the community is very high. The general trust in foreign people based on empathy in $\mathrm{Z}$ is much stronger than in the Hungarian settlements participating in the 2005 International Comparative Value Assessment. And the situation was even better in case of the strategic trust (the trust in family members and friends). The overwhelming majority of the population trusts their relatives and friends, and through social support, it is easier to survive the more difficult times. Our survey revealed that personal contact is common among members of the community. This is not surprising, as due to the size of the village, almost everyone knows everyone, so they often talk to each other.

The central element of the local development was establishing the Children's Home and Diaspora School Centre. The School Centre was opened in 1996. In order to supply the home, there was a need to create different economic units (horticulture, dairy farm, mill and bakery). These operate partly independently, provide economic self-sufficiency, and supply the area around the village with various products (Farkas and Kassai, 2014).

We can conclude that the development required more than one factor for success. On the one hand, some local heroes did not spare themselves in the community and launched the developments. Actors initiating the development had a strong external relationship and strong initiative. On the other hand, there were also external supporters and resources. Thirdly, the local community had and has resources that could also be relied upon.

\section{I village}

I- from an economic and social point of view - is a disadvantaged settlement located in the southeastern part of Nógrád County, Hungary. In 2015, its population was 118 people. In the last decades, significant social and economic problems have arisen in the village. The most serious problems were the unemployment and the deterioration of the local community life. A significant 
proportion of the population has a low level of education; the emigration of young people with higher education is characteristic, and as a result, the aging of the local society has increased.

The situation of the local society in I is determined by three distinct groups, the indigenous village people, the indigenous village people of noble birth and the new settlers. The different values and ways of thinking were also revealed during the questionnaire interviews. Without co-operation between the indigenous people and the newcomers, the development of the settlement is inconceivable.

Agriculture has always been an important sector of the economy of $\mathrm{I}$, but it has not provided an adequate livelihood for everyone. Regarding the structure of farming, there is a shift from field crop production to grazing livestock breeding and beekeeping. The transformation into a holiday village or the use of holiday homes in the absence of local resources is possible only with the help of external resources. Indigenous people, in the absence of adequate incomes, have been unable to make old houses suitable for rural tourism (Farkas and Kenderfi, 2015).

In the case of I, the inherited economic and social conditions and the situation of the local society negatively affect the development opportunities. Co-operation between local and micro-regional actors is very weak. The low level of human resources, the weakness of civil organizations, the distorted social structure all contribute to the dominance of distrust and envy in the examined settlement. The operation of existing foundations is typically linked to the new settlers. However, we cannot talk about local heroes or innovators in the village.

\section{$B$ village}

$B$ is a village in Bács-Kiskun County, Hungary with a population of 2,073 in 2019. In the 1990s and even more in the 2000s, the number of births was extremely low. The trend also continued after 2011. The increase of the proportion of immigrants may theoretically increase the number of villagers; however, a quarter of the interviewed persons replied that they would leave the settlement in the future. Despite turbulences in population dynamics, the population stabilized in the last few years.

The results of the questionnaire survey in 237 households showed that trust is not an important component of the social capital in B as in other villages. General trust based on empathy for foreign people is very weak. The research has also highlighted that trust in the local community is usually limited to their family members and friends, which means that we have found very positive results in terms of strategic trust (Farkas and Kolta, 2017).

$B$ belongs to the characteristic villages that differed by their horticultural production from the villages practicing general agriculture. The main products here are paprika, garlic and head cabbage. With help of intensive horticulture production, a new entrepreneur group emerged in the village, who plays an important role in the decision-making process of the village. Thus, the basis of the developments lies in the favourable farming opportunities. The significant private farms have provided a secure basis for livelihoods for decades. At the same time, the use of external resources gained more and more importance.

\section{K village}

$\mathrm{K}$ is a commune center along the road E60, next to Huedin in Romania. From the 1940 s to the 1950s, declining birth rates and outmigration led to a decrease in the population. However, significant population decline occurred in the 1970s and 1980s. In recent decades, depopulation has been a typical process. Low birth numbers have and will have significant negative consequences. The age structure of the village is getting older and it will be more and more difficult to provide the appropriate number of children for the primary school. In the longer term, active, working age population will decrease, too. Recent population is about 950 people.

The history of the development of the village is not unique in the ethnographic literature, but it is very different from the livelihood strategies of the surrounding villages. There are evidences when some of the villages dealing with farming are distinguished by craft or artisan activity. This change of livelihood strategy at the turn of the $20^{\text {th }}$ century also relied on internal and external resources, 
which fortunately strengthened each other's impact. The craft industry has transformed the local society, but the role of basic values, family, religion, school, and national identity has not changed (Farkas and Kolta, 2018).

The strength of social capital can be claimed to be relatively good. In K, the strategic social capital is stronger than general trust. The situation is worse in the case of anomie; the norm uncertainty in the villages can be caused mainly by lower level of education and secondly by the division of the local society. The biggest problem of the village is the social and political division. To reach significant progress, it is inevitable to develop rural development strategy and co-operate with neighbouring settlements. This will be very difficult to achieve with a weak local society, low civil activity, extremely poor communication, poor human resources, low co-operation, and political division.

\section{T village}

$T$ is located in the Ciuc Basin, in Romania. The population of the village is about 2,600 people. Agriculture has been the basis of the village's livelihood for many centuries, but according to Orbán (1868), quarrying also took place in the second half of the $19^{\text {th }}$ century. Furthermore, forestry has always been of great importance. Between the two world wars, craft activity was also significant. According to our interviewees, people worked in the fields in the summer, and cut down forests in the winter. Hemp processing was significant. However, traditional farming has become less and less a secure livelihood since the 1950s. Nowadays, EU's rural development subsidies provide a modest livelihood for village farmers.

The adult population of the village can be divided into four major groups in terms of labour force. The first group includes those who farm in T; carry out self-sufficient (self-employed) or market production on a smaller or larger plot of land. Another group - smaller than the previous one has jobs in other parts of Romania and in Széklerland. The third group belongs to guest workers who take up work abroad, usually in the following countries: Germany, Austria, and Switzerland. The average age of guest workers is increasing, older ones are also leaving for a few months; in two months, they earn as much as they would at home in one year. The fourth group includes the elderly and pensioners. Employment is often characterized by seasonality and periodicity.

The strength of social capital was judged by measuring trust. In T, both the level of general and strategic trust is relatively high. Nearly half of those surveyed also trust strangers, not feeling they would take advantage of them. Trust in friends is common to more than $80 \%$ of respondents, but family members trust people almost without exception. Compared to the results of research in other villages, it can be concluded that the general trust in $\mathrm{T}$ is high, although not the highest. Trust in friends is also high, but lower than the average of the settlements analyzed in Hungary so far. At the same time, trust in family members is the highest among the settlements studied. Overall, the level of trust is high in the community, and its pattern presupposes a degree of conservative value system (Farkas and Kolta 2020).

Based on the interviews, it seems that decisions are made in a narrow circle in the village, despite the fact that there are also village rallies and street rallies. Official civil activity is quite low in T. We found out that neither the external (infrastructural, natural) nor the internal (community-social) conditions are favourable. The functioning of the local community is well indicated by the fact that the informal economy is very widespread, the members of the community work closely together on a daily basis. Compared to previous village research, people are the happiest in the surveyed settlement. At the same time, trust in family members was also the highest, but the degree of anomie was quite low.

\section{Discussion}

The study of social capital is growing and becoming increasingly important in rural development. It is part of the rural network already described by some authors (Guinjoan et al., 2016). Our research has confirmed that the presence of social capital, as described by Böhm and Pál (1983), is related to communication, but the diversity of cultural identities, see Lee et al. (2005), has not been reported in relation to local social capital. In the villages studied, strong social capital was 
more likely to contribute to the strengthening of local identity. We agree with Wiesinger (2007) that it is difficult to determine how the state can facilitate the embedding of social capital at the local level, but it should certainly attempt to do so. Although social capital can also reinforce negative local or national social phenomena such as corruption (see Voicu - Basina, (2005); Fazekas and Tóth (2010); (Swendsen, 2003), it is proved, that the role of social capital in the development of local society and economy is more likely to be positive.

The state of social capital was assessed in several ways. On the one hand, we took into account the number and functioning of civil society organisations, communication within the community, participation in development, and on the other hand, we tried to quantify the experience of local society functioning. In practice, social capital is assessed by measuring trust. In our research, we generally measured three types of trust: general trust and strategic trust in friends and family. In general, in Hungarian villages (I, B) trust in friends was more important than in Transylvanian villages. The level of general trust was highest in village $Z$. It was not far behind the level of trust in $\mathrm{T}$.

Tab 1. Level of trust in the surveyed municipalities (percentage of "agree" and "strongly agree" responses, \%). Source: Questionnaire surveys of the given village research camps

\begin{tabular}{|l|c|c|c|}
\hline & $\begin{array}{c}\text { General } \\
\text { trust }\end{array}$ & \multicolumn{2}{|c|}{ Strategic trust } \\
\hline Settlements & & Friends & Family members \\
\hline Z & 57 & 75 & 97 \\
\hline $\mathrm{I}$ & 46 & 85 & 91 \\
\hline $\mathrm{B}$ & 35 & 85 & 94 \\
\hline $\mathrm{K}$ & 40 & 78 & 97 \\
\hline $\mathrm{T}$ & 49 & 82 & 98 \\
\hline
\end{tabular}

The results of the studies implemented in summer research camps varied, but some general conclusions can be drawn. The following table summarizes the main findings of the research. It is evident that the villages are different in terms of the actors of development, planning, the use of external assistance, the state of local partnership, the aspects of social participation and sustainability. With the help of the presented analytical model, the development and the social capital of the villages can be evaluated. We situated the villages in the following grid. Communities and their quality of life in the box with strong local capital and with successful development, activities are in the best position and conversely settlements in the box with weak social capital and development failures are in the worst situation.

Fig 2. Characteristics of the local development in analyzed villages. Source: Own contribution

\begin{tabular}{|c|c|c|c|c|c|c|}
\hline \multirow{2}{*}{$\begin{array}{l}\text { Direction of } \\
\text { development }\end{array}$} & \multicolumn{6}{|c|}{ Social capital } \\
\hline & High & & & & & Low \\
\hline Developing & Z & $\mathbf{T}$ & $\mathbf{v}$ & $\begin{array}{l}\text { B } \\
\text { M }\end{array}$ & K & \\
\hline Regressive & & & & & & \\
\hline
\end{tabular}


Figure 2 shows that $Z$ is the most suitable for participating in the developments, while $I$ is the least. In $\mathrm{V}$, the lack of local endogenous resources was one of the most important problems. There, the development opportunities were represented by the village renovation, village landscape preserving and tourism program. Starting tourism is not an easy task, as it cannot be operated without the involvement of the local community, which was not ready for this task.

In $\mathrm{M}$, we found an interesting correlation between the lack of water supply and the situation of women. ${ }^{7}$ Divide and dissension could hinder the local development process very much. This was equally true in $\mathrm{M}$ and in $\mathrm{I}$. However, the fact that many local initiatives, programs and development attempts have not been used properly is the responsibility of the local community itself. If the local community fails to get involved in the development, it will cease, or remain unused. In similar cases, developers need to think about ways to activate the local community, strengthen local identity, and establish a partnership between actors inside and outside the village, i.e. how to revitalize the village.

On the contrary, in Z, the strength of social capital has helped to implement developments and integrate external and endogenous resources. In the vast majority of the population, strong confidence and social support make it easier to survive more difficult times. There were several factors that needed lucky co-ordination for the development. For example, there were local heroes who did not spare themselves in the community and launched the developments.

Examining the role of social capital in the development process raises further questions. For the time being, we cannot answer the question whether strong social capital causes development or, conversely, it is a consequence of development. However, we can safely state that if the developments go hand in hand with a higher social capital, the quality of life of the people living in the settlements will be higher. We can also declare that it is only worthwhile to start development if we involve and develop the community from the very beginning.

When we think about the development of a settlement, we often think of infrastructure deficiencies, the low level of services or bad demographic conditions. Few people think that they have to also examine the trust, the co-operation and connections of the local society. In our opinion, this is important because if the cohesion of the local society is weak, there is a potential for real conflicts. When the community is able to engage in a dialogue inside and outside, obtaining the necessary resources will only be a minor problem.

\section{Summary}

In the research camps - among different topics - we focused on the role of the social capital in the rural development. Summarizing the views of different authors, we agreed, that social capital is a mixture of trust, relationships, norms of social behaviour and civil social activity, which strongly affects the local development process. This paper analysed the development progress and possibilities of seven different villages in Romania and in Hungary. In our opinion, there is connection between the state of the local society and the inherited socio-economic conditions, but without strong local society and social capital, the community is not able to use its endogenous resources. As it was demonstrated, in the development of villages, the role and relationship of NGOs, entrepreneurs, municipalities (local governments) and local heroes are of great importance. Just as strong community participation and social capital could compensate the inherited disadvantage and contribute to development, the local conflicts, tensions, party interests could undermine the best development possibilities.

Research in the village research camps was not only aimed at investigating social capital, but also played an important role in exploring local socio-economic characteristics and quality of life. This also meant that the situation of local society was studied from a wide variety of perspectives.

\footnotetext{
7 When our research began, the village did not have a pipeline network for drinking water and sewerage. The housewives were responsible for providing the water supply. They spent most of the time visiting various wells and managed water supply. In this situation, they were not able (and supposed) to visit workplaces (and having driving licences) in the neighbouring city.
} 
These have therefore both helped and hindered our understanding of the role of social capital. On the whole, however, it can be concluded that the studies carried out in the village research camps were sufficient to assess the social capital of each settlement. In the following, we will return to the research sites and will also analyse changes in social capital over time through further studies. The village research camp as a research method can be extended. The growth of empirical experience in the field could lead to a breakthrough in this research area.

\section{Academic references}

[1] Bíró, Z. (2002). A mezőmadarasi helyi közösség müködésének a vizsgálata/Analysis of function of the local community in Madaras. Csíkszereda: KAM - Regionális és Antropológiai Kutatások Központja.

[2] Bourdieu, P. (1986). The forms of capital. In Angelus, R., ed., A társadalmi rétegzödés komponensei. Budapest: Új Mandátum.

[3] Bőhm, A. \& Pál, L. (1983). Helyi társadalom I. kötet Hipotézisek, kutatási módszerek. Budapest: MSZMP KB Társadalomtudományi Intézete.

[4] Coleman, J. S. (1988). Social Capital in the Creation of Human Capital. The American Journal of Sociology, 94 (Supplement), 95-120.

[5] Dufhues, T., Buchenrieder, G. \& Fischer, I. (2006). Social capital and rural development: literature review and current state of the art [Discussion paper No. 96]. Halle a.s.: Leibniz Institute of Agricultural Development in Central and Eastern Europe.

[6] Farkas, T. \& Dávid L., eds. (2010). Székelyvécke avagy egy falukutató tábor tapasztalatai Gödöllő: Szent István Egyetemi Kiadó.

[7] Farkas, T. \& Kassai, Zs., eds. (2014). Zsoboki tanulmányok. Gödöllő: Szent István Egyetemi Kiadó.

[8] Farkas, T. \& Kenderfi, M., eds., (2015). Cserhátszentiváni tanulmányok. Gödöllö: Szent István Egyetemi Kiadó.

[9] Farkas, T. \& Kolta, D., eds., (2017). Bátyai tanulmányok. Gödöllő: Szent István Egyetemi Kiadó.

[10] Farkas, T. \& Kolta, D., eds. (2018). Körösföi tanulmányok. Gödöllö: Szent István Egyetemi Kiadó.

[11] Farkas, T. \& Kolta, D. (2020). Csíkszenttamási tanulmányok. Gödöllö: Szent István Egyetemi Kiadó.

[12] Fazekas, M. \& Tóth, I. J. (2015). From Corruption to State Capture: A New Analytical Framework with Empirical Applications from Hungary. Political Research Quarterly 69(2), 320-334. DOI: 10.1177/1065912916639137.

[13] Fukuyama, F. (2001). Social capital, civil society and development. Third World Quaterly, 22(1), 7-20. DOI: 10.1080/101436590020022547.

[14] Füzér, K., Gerö, M., Sik, E. \& Zongor, G. (2005). A társadalmi tőke növelésének lehetőségei fejlesztéspolitikai eszközökkel. Fejlesztéspolitika társadalmi hatásai 4. Budapest: TÁRKI. Accessed 2011.07.13. Retrieved from. http://www.tarki.hu/adatbank-h/kutjel/pdf/a768.pdf

[15] Guinjoan, E., Badia, A., Tulla., A. (2016). The new paradigm of rural development. Theoretical considerations and reconceptualization using the 'rural web'. Boletín de la Asociación de Geógrafos Españoles 71, 495-500.

[16] Gusti, D. (1976). A szociológiai monográfia. Bucharest: Kriterion Könyvkiadó.

[17] Kassai, Zs., Pocol, C. \& Farkas, T. (2016). The Presence or the Absence of Schools: What Impact for Rural Communities in Hungary and Romania? Bulletin UASVM series Agriculture 73(1), 35-43. DOI: 10.15835/buasvmcn-agr: 12020. 
[18] Kłoczko-Gajewska, A. (2020). Long-term impact of closing rural schools on local social capital: a multiple-case study from Poland. European Countryside 12(4), 598-617. DOI: 10.2478/euco-2020-0031.

[19] Kulcsár, L. (2017). A vidékfejlesztés elméleti megközelítése: regionális és kulturális összefüggések. Kolozsvár: Kriterion könyvkiadó.

[20] Lee, J., Árnason, A., Nightingale, A. \& Shucksmith, M. (2005). Networking: Social Capital and Identities in European Rural Development. Sociologia Ruralis, 45, 269283. DOI: 10.1111/j.1467-9523.2005.00305.x.

[21] Ludescher, G. (2009). A helyi társadalmak szerepe a falvak sikerességében [PhD theses]. Pécs: University of Pécs.

[22] Luloff, A. E. \& Bridger, J. (2003). Community Agency and Local Development. In: David L. Brown, Louis E. Swanson with assistance from Alan W. Barton: Challenges For Rural America In The Twenty-First Century. 203-213.

[23] Orbán, A. \& Szántó, Z. (2005). Társadalmi tőke. Erdélyi Társadalom 3(2), 55-70.

[24] Orbán, B. (1868). A Székelyföld leírása - Történelmi, régészeti, természetrajzi s népismei szempontból. Pest: Panda és Frohna Könyvnyomdája.

[25] Pisani, E. \& Micheletti, S. (2020). Social capital and rural development research in Chile. A qualitative review and quantitative analysis based on academic articles. Journal of Rural Studies 80, 101-122. DOI: 10.1016/j.jurstud.2020.08.002.

[26] Polèse, M. \& Shearmur, R. (2006). Why some regions will decline: A Canadian case study with thoughts on local development strategies*. Papers in Regional Science, 85, 23 46. DOI: 10.1111/j.1435-5957.2006.00024.x.

[27] Putnam, R. D. (1993). The Prosperous Community: Social Capital and Public Life. The American Prospect 13(4), 35-42.

[28] Schafft, K. \& Brown, D. 2003). Social capital, social networks, and social power. Social Epistemology 17(4), 329-342. DOI: 10.1080/0269172032000151795.

[29] Semczuk, M. (2020). The Impact of the Closure of Primary Schools on the Economic Development of Rural Areas in Małopolska Voivodeship. Przedsiębiorczość - Edukacja 16(1), 247-256. DOI: 10.24917/20833296.161.20.

[30] Svendsen, G. T. (2003). Social Capital, Corruption and Economic Growth: Eastern and Western Europe [Working Paper 03-21]. Department of Economics Aarhus School of Business.

[31] Tömpe, F. (2007). A társadalmi töke mértékének és hatásának vizsgálata a farmgazdaságok körében. Gödöllö: Szent István University.

[32] Voicu, B. \& Basina, T. (2005). Social capital and civic participation in Ukraine and Romania. In Rusu, H. \& Voicu, B., eds., Perspectives on the European Postcommunist Societies (pp. 75-96). Sibiu: Psihomedia.

[33] Westlund, H. \& Kobayashi K., eds. (2013). Social capital and sustainable urban-rural relationships in the global knowledge society. Cheltenham: Edward Elgar. DOI: $10.4337 / 9781782540601$.

[34] Wiesinger, G. (2007). The importance of social capital in rural development, networking and decision-making in rural areas. Journal of Alpine Research 95(4), 43-56. DOI: $10.4000 /$ rga.354. 
[35] Farkas, T. (2010). A Mezőmadaras községben lezajlott fejlesztési tevékenységek társadalmi hatás-vizsgálata (unpublished manuscript).

[36] Hoelting, J. (2017). Building trust in communities. UMN Extension https://extension.umn.edu/vital-connections/building-trust-communities. 